\begin{tabular}{|l|l|l|}
\hline \multicolumn{2}{|c|}{ PublisherInfo } \\
\hline \hline PublisherName & $:$ & BioMed Central \\
\hline \hline PublisherLocation & $:$ & London \\
\hline \hline PublisherImprintName & $:$ & BioMed Central \\
\hline \hline
\end{tabular}

\title{
Plasmodium $\mathrm{Py} 235$ profiles
}

\begin{tabular}{|l|l|l||}
\hline \multicolumn{2}{|c|}{ ArticleInfo } \\
\hline \hline ArticleID & $:$ & 4374 \\
\hline \hline ArticleDOI & $:$ & $10.1186 /$ gb-spotlight-20020111-01 \\
\hline \hline ArticleCitationID & $:$ & spotlight-20020111-01 \\
\hline \hline ArticleSequenceNumber & $:$ & 40 \\
\hline \hline ArticleCategory & $:$ & Research news \\
\hline \hline ArticleFirstPage & $:$ & 1 \\
\hline \hline ArticleLastPage & $:$ & 2 \\
\hline \hline & $:$ & RegistrationDate : 2002-01-11 \\
ArticleHistory & $:$ & OnlineDate $\quad$ 2002-01-11 \\
\hline \hline ArticleCopyright & $:$ & BioMed Central Ltd2002 \\
\hline \hline ArticleGrants & $:$ & \\
\hline \hline ArticleContext & $:$ & 130593311 \\
\hline \hline
\end{tabular}




\section{Jonathan B Weitzman}

Email: jonathanweitzman@hotmail.com

The Plasmodium yoelii yoelii genome contains around 35 genes encoding $235 \mathrm{kD}$ rhoptry proteins (Py235) that are involved in erythrocyte invasion and parasite virulence. In the January 11 issue of Science, Preiser et al. describe the transcription pattern of py 235 genes during the parasite's life cycle and their role in cell invasion (Science 2002, 295:342-345). Immunofluorescence analysis using antibodies recognizing distinct Py235 proteins revealed differences between pre-erythrocytic and erythrocytic parasites. Antibodies to Py 235 expressed in the sporozoite were found to inhibit invasion, whereas those to the blood stage proteins were not. They analyzed stage-specific expression of py 235 transcripts by RT-PCR, and found that genes transcribed in the sporozoite and hepatic forms differed from those in the erythrocytic parasite. Non-overlapping sets of $p y 235$ genes are associated with the sporozoite, hepatic schizont and erythrocytic schizont developmental stages. The distinct rhoptry proteins in the sporozoites and liver stages, may offer specific targets for vaccination strategies aimed at pre-erythrocyte malaria parasites.

\section{References}

1. Identification of the gene for a Plasmodium yoelii rhoptry protein. Multiple copies in the parasite genome.

2. Science, [http://www.sciencemag.org] 